Tumou Tou, Volume VII, Nomor 2:157-171

ISSN 2355-3308 (Cetak), ISSN 2745-9527 (Online)

\title{
PEMAHAMAN PEMUDA TENTANG IBADAH PEMUDA DI JEMAAT YEDIDYDIAH ABANGIWANG KLASIS PANTAR TIMUR
}

\author{
Julinda Leko, \\ gesalindaleko@gmail.com \\ Nelci Nafalia Ndolu \\ nelcinafaliandolu@gmail.com \\ Institut Agama Kristen Negeri (IAKN) Kupang
}

Diterima 22 April 2020

Disetujui 20 Mei 2020

\begin{abstract}
ABSTRAK
Ibadah pemudah merupakan salah satu program gereja untuk meningkatkan Pemahaman Pemuda Tentang Ibadah Pemuda dengan Tujuan untuk menumbukan Iman pemuda karena ketika iman kepercayan pemuda semakin bertumbuh, maka pemuda akan terus mewartakan Injil di manapun pemuda berada dan selalu berpegang teguh pada kebenaran Firman Tuhan (Turang, 2006:12). Pemahaman pemuda tentang ibadah pemuda sudah sangat baik, sebab gereja melakukan beberapa kegiatan seperti Ibadah pemuda, Pemahaman Alkitab, Retret dan Musyawarah Belajar (Musbel). Penelitian ini menggunakan metode wawancara dengan analisis Kulitatif. Analisis digunakan untuk memahami hubungan dan konsep dalam data sehingga hopotesis dapat dikembangkan dan dievaluasi (Sugiyono, 2018:244). Dari hasil penelitian dapat disimpilkan bahwa Pemahaman Pemudah tentang Ibadah pemudah sudah sangat baik dan dapat meningkatkan pertumbuhan iman pemuda Gereja Yedidtyah Abangiwang.
\end{abstract}

Kata Kunci: Pemahaman Pemuda tentang Ibadah Pemuda, Alkitab, Retret dan Musbel.

\section{PENDAHULUAN}

\section{Latar Belakang Masalah}

Kehidupan kaum muda hanya bisa berkembang dengan benar jika nilai- nilai Injil menjadi milik dan bagian hidup mereka. Kebanyakan kaum muda merasa asing dengan nilai-nilai Injil karena pewartaan gereja kurang 
menyentuh jiwa mereka. Pewartaan gereja masih terpengaruhi oleh ajaran dan tindakan normatif. Hal ini sering mejadi kendala bagi kaum muda untuk merasa tertarik pada seperangkat tindakan ritual-liturgi atau ajaran-ajaran moral normatif. Memang geraja perlu mengajarkan nilai-nilai normatif dan harus tetap menjaganya terhadap perkembangan ilmu dan teknologi, tetapi gerja perlu juga memikirkan sebuah aggiornamento atas metode pewartaan nilai-nilai normatif. Yesus mengajar para murid agar taat pada hukum, peraturan dan adat-istiadat yang ada dalam lingkungan Yahudi, tetapi bersama dengan permintaan itu, Ia mengoreksi praktek hukum, peraturan yang tidak mendatangkan nilai pembebasan bagi masyarakat (Turang, 2006: 11).

Dari teori diatas penulis mengambil kesimpulan bahwa pemuda selalu dikatakan sebagai tulang punggung gereja atau pemuda sebagai tiang induk gereja. Oleh sebab itu, gereja harus memberikan perhatian penuh kepada pemuda dalam mengembangkan talenta yang ada dalam diri pemuda. Gereja juga harus mendukung pemuda dalam kegiatan kerohanian dalam hal ini ibadah pemuda. Gereja seharusnya selalu hadir dalam setiap ibadah pemuda, sehingga pemuda juga bisa merasakan bahwa adanya rasa peduli terhadap mereka. Gereja tidak hanya hadir saja dalam ibadah pemuda, tetapi harus menjadi sahabat bagi pemuda dalam menjalankan misi Allah di tengah-tengah dunia ini.

Gereja perlu terbuka terhadap kaum muda dan perlu memberi peran utama dalam aspek-aspek pewartaan gerejani yang sesuai dengan roh mereka. Jika gereja bisa peduli dan bersikap terhadap kaum muda, maka gereja akan hadir sebagai sahabat dan penyelamatan bagi dunia dewasa ini. Gereja yang menjadi sahabat dan penyelamatan dunia adalah gereja yang tidak saja dipenuhi dengan tindakan ritual, tetapi gereja yang mampu mengarahkan mayoritas penduduk dunia kepada penerimaan pesan keselamatan Tuhan.

Ketika pewartaan gereja tidak menyentuh jiwa pemuda, maka gereja harus memikirkan sesuatu untuk memperbaharui cara pewartaannya itu. Oleh karena itu, gereja harus mempertajam pewartaan yang kuat melalui Injil kebenaran Firman Tuhan, sehingga pemuda bisa menerima dan 
merasa dirinya tidak asing lagi. Gereja terus mewartakan Injil kebenaran di tengah-tengah perkumpulan persekutuan pemuda, sehingga iman kepercayaan pemuda semakin bertumbuh dan berkembang. Ketika iman kepercayan pemuda semakin bertumbuh, maka pemuda akan terus mewartakan Injil di manapun pemuda berada dan selalu berpegang teguh pada kebenaran Firman Tuhan (Turang, 2006: 12).

Dari pendapat di atas penulis mengambil kesimpulan bahwa gereja telah berusaha memberikan pengajaran iman, pendidikan dan pembinaan terhadap organisai-organisasi salah satu bentuknya ialah adanya ibadah pemuda yang dilakukan di setiap wilayah, ada juga ibadah gabungan pemuda jemaat, sekaligus melakukan Pemahaman Alkitab (PA). Gereja juga telah memenuhi apa yang menjadi kebutuhan pemuda dalam melakukan ibadah pemuda, akan tetapi seiring berjalannya waktu pemuda gagal dalam menjalankan apa yang menjadi tugas dan tanggung jawab bagi orang muda. Pemuda tidak mau lagi melakukan ibadah pemuda di setiap rayon-rayon, bahkan pemuda juga jarang mengikuti kebaktian utama disetiap hari Minggu. Untuk itu, pemuda harus menyadari bahwa ibadah itu sangat penting, karena dengan melakukan ibadah, maka iman pemuda semakin bertumbuh lebih baik, dengan beribadah juga pemuda dapat mempersiapkan diri menjadi pemimpin, karena kedepannya pemudalah yang akan menggantikkan orang-orang tua untuk menjadi majelis dalam jemaat.

Ibadah adalah kegiatan rohani yang harus dilakukan oleh orang Kristen. Karena melalui ibadah, orang percaya berjumpa dengan Tuhan Yesus Kristus sehingga dapat mengenal Dia secara pribadi. Ibadah juga perbuatan yang menyatakan bakti kepada Allah yang didasari pada ketaatan untuk mengerjakan perintah-Nya dan menjauhi larangan-Nya, dilakukan dengan segenap hati, lahir dan batin, sesuai dengan perintah Tuhan untuk mendapatkan kebahagiaan dan keselarasan hidup, baik terhadap diri sendiri, keluarga, masyarakat maupun terhadap alam semesta. Sangat jelas bahwa ibadah merupakan keharusan kepada setiap orang Kristen (Alen, 2003: 15).

Dari pendapat di atas penulis mengambil kesimpulan bahwa dengan 
melakukan ibadah maka pemuda akan berjumpa dengan Yesus. Ketika ibadah dilakukan dengan sungguh-sungguh, tulus, mau menyerahkan seluruh kehidupan kepada Tuhan, dan siap menerima Tuhan sebagai Juruselamat, maka pemuda akan mengenal Dia secara pribadi. Ketika sudah menerima Tuhan, maka harus melakukan perintahperintah-Nya, dan menjauhi semua perbuatan-perbuatan yang tidak diinginkan Tuhan. Sebagai orang Kristen ibadah sangat penting dilakukan.

Hal ini dikarenakan mereka menghadapi kehidupan tanpa memiliki kepastian arah yang pasti. Mereka perlu ditolong menyadari bahwa mereka memikul harapan banyak kepentingan di masa depan, dan karenanya perlu dipertimbangkan sebagai suatu tanggung jawab yang perlu disikapi dan dipersiapkan secara sengaja dan matang. Pelayanan pemuda sudah menjadi pelayanan kategorial dari gereja-gereja yang ada di Indonesia (Thayer, 2007: 137).

Melalui hasil pengamatan, dari ketidak hadiran pemuda dalam melakukan ibadah, karena adanya ketidak salah pahaman antara pemuda dengan ketua pemuda jemaat, pemuda dengan koordinator wilayah, dan pemuda dengan majelis harian. Hal inilah menjadi faktor yang mempengaruhi pemuda dalam mengikuti ibadah pemuda. Sehingga, kebanyakan laki-laki lebih memilih berada di pantai dan di pinggir jalan raya, dari pada berada di rumah ibadah. Begitu pula dengan perempuan, ada orang tua yang tidak mengijinkan anak perempuannya untuk mengikuti ibadah pada malam hari.

Berdasarkan latar belakang masalah, maka yang menjadi fokus dalam penelitian ini adalah pemahaman pemuda tentang ibadah pemuda.

\section{METODOLOGI PENELITIAN}

Tempat penelitian ini akan dilakukan di Jemaat Yedidyah Abangiwang, Klasis Pantar Timur. Penelitian ini akan berlangsung selama satu bulan setelah proposal ini diseminarkan. Jenis-jenis metode penelitian dapat diklasifikasikan berdasarkan, tujuan, dan tingkat kealamiahan objek yang diteliti. Berdasarkan tujuan, metode penelitian dapat diklasifikasikan menjadi, penelitian dasar, penelitian terapan, dan penelitian pengembangan (Sugiyono, 2018:4). Dari penelitian ini 
penulis menggunakan jenis penelitian kualitatif. Metode penelitian kualitatif adalah metode penelitian yang berlandas pada filsafat postpositivisme, digunakan untuk meneliti pada kondisi objek yang alamiah, dimana peneliti adalah sebagai instrument kunci, teknik pengumpulan data dilakukan secara triangulasi (gabungan), analisis data bersifat induktif/kualitatif, dan hasil penelitian kualitatif lebih menekankan makna dari pada generalisasi (Sugiyono, 2018:9).

Teknik pengumpulan data merupakan langkah yang paling strategis dalam penelitian, karena tujuan utama dari penelitian adalah mendapatkan data. Tanpa mengetahui pengumpulan data, maka peneliti tidak akan mendapatkan data yang memenuhi standar data yang ditetapkan (Sugiyono, 2018:224). Dalam peneliti ini penulis menggunakan teknik pengumpulan data, yaitu teknik wawancara. Wawancara merupakan pertemuan dua orang untuk bertukar informasi dan ide melalui tanya jawab, sehingga dapat dikontruksikan makna dalam suatu topik tertentu (Sugiyono, 2018:231).

$$
\text { Esterbreg (2002) menemukan }
$$
beberapa macam wawancara, yaitu:
Pertama: wawancara terstruktur. Wawancara terstruktur digunakan sebagai teknik pengumpulan data, telah mengetahui dengan pasti tentang informasi apa yang diperoleh. Kedua: wawancara semi-struktur. Jenis wawancara ini sudah termasuk dalam kategori in-dept interview, dimana ada pelaksanaannya lebih bebas bila dibandingkan dengan wawancara terstruktur. Tujuan dari wawancara jenis ini adalah untuk menemukan permasalahan secara lebih terbuka, dimana pihak yang diajak wawancara diminta pendapat, dan ide-idenya. Ketiga: Wawancara tak berstruktur. Wawancara tidak berstruktur, adalah wawancara yang bebas dimana peneliti tidak menggunakan pedoman wawancara yang telah tersusun secara sistematis dan lengkap untuk pengumpulan datanya (Sugiyono, 2018:233).

\section{HASIL DAN PEMBAHASAN}

\section{Hasil}

\section{Ibadah Pemuda}

Berdasarkan item pembahasan ini, Ibadah Pemuda biasanya dilakukan pada setiap hari senin dengan asumsi agar para pemuda yang mengikuti Ibadah dapat mengawali hari yang baru 
dengan memiliki bekal kerohanian yang baik untuk dapat digunakan selama sepekan lamanya. Dari hasil wawancara dengan kelima Narasumber, terdapat dua narasumber yang memiliki jawaban yang sama yaitu ibadah yang dilakukan pada hari Senin sangat bermanfaat bagi pemuda dalam hal pertumbuhan iman dan pengenalan akan Yesus Kristus Sang Juruselamat (FI J1, GU J1). Kemudian Narasumber yang satu mengatakan bahwa ibadah pemuda yang di lakukan hari Senin mengubah kepribadian pemuda dalam kerohanian'berjiwa sosial dalam berlingkungan. Karena dalam masah modern ini banyak tantangan dunia yang membuat pemuda/pemudi muda terpengaruhi dalam hal-hal (kriminal) di masah kini, jadi ibadah pemudah sangat penting bagi pemuda (YL J1). Lalu Narasumber yang satu lagi berpendapat bahwa ibadah yang dilakukan pada hari Senin itu baik karena ibadah dilakukan pada awal minggu sehingga memberi semangat dan motivasi dalam manjalani hari-hari berikutnya (RD J1). Kemudian Narasumber yang satunya lagi menjawab bahwa ibadah pemuda yang dilakukan pada hari Senin itu sangat penting karena di situ pula kita beribadah, memuji, memuliakan nama Tuhan, mendengarkan Firman Tuhan, dan di situ pula kita belajar tentang apa yang ada dalam isi Alkitab yang kita tidak tahu kita pasti tahu dan pasti melakukan dalam kehidupan sehari-hari (TU J1).

Ibadah Pemuda perlu dilakukan karena pemuda sebagai tulang punggung gereja harus dibekali dengan nilai - nilai spiritual yang terkadung di dalam Alkitab sehingga menjadi pedoman dalam menjalani kehidupan sehari - hari. Narsumber memahami bahwa perlunya ibadah pemuda dilakukan sebab di era yang modern sekarang, pemuda sebagai tulang punggung gereja, harus dibekali dengan nilai kerohanian yang baik, pehaman Alkitab yang baik, dan juga menumbuhkan iman dengan baik (YL J2, RD J2, FI J2, TU J2, GU J2). Di era globalisasi sekarang, pengembangan nilai spiritual sangatlah penting agar dapat menjadi modal untuk terhindar dari hal - hal yang dapat menjerumuskan. Salah satu cara untuk meningkatkan nilai spiritual yaitu dengan diadakannya Ibadah Pemuda.

Tujuan diadakannya Ibadah pemuda yaitu sebagai wadah atau 
tempat untuk mengajarkan pemuda agar lebih mengenal dan mendekatkan diri dengan Allah, serta mengarahkannya ke jalan yang benar berdasarkan Firman Tuhan. Narasumber memahami bahwa Tujuan ibadah pemuda yaitu untuk membentuk karakter pemuda (YL J3, FI J3, TU J3). Narasumber yang satu lagi berpendapat bahwa Tujuan ibadah pemuda yaitu mempersatukan pemuda gereja dan wadah untuk menerima dan memahami isi Alkitab serta pertumbuhan iman (RD J3). Narasumber berikut mengatakan bahwa tujuan ibadah pemuda yaitu menumbuh kembangkan iman pemuda (GU J3). Kelima Narasumber juga mengusulkan agar ibadah pemuda tidak saja hanya dilakukan di rumah saja, tetapi kalau bisa ibadah pemuda dilakukan di pantai dan tempat-tempat terbuka (YL J3), ibadah pemuda harus tetap dilaksanakan setiap Senin (RD J3 GU J3), ibadah dilakukan dengan metode-metode yang menarik agar pemuda dapat bersemangat dan rajin mengikuti ibadah pemuda (FI J3). Ibadah harus dilakukan tepat waktu dan seluruh pemuda harus ikut berpartisipasi (TU J3).

\section{Pemahaman Alkitab}

Alkitab merupakan sebuah buku yang berisi tentang petunjuk dan pedoman hidup bagi umat Kristen. Narasumber memahami akan hal itu sehingga mereka mengeluarkan segmen tentang pemahaman Alkitab yaitu pemahaman Alkitab mendorong dan mengajarkan saya pada hal-hal baik yang di mana salah satu kitab mengajarkan kepribadian saya tentang berlingkungan yang baik “jangan mengini barang sesama, hormatilah ayah dan ibumu supaya lanjut usia mu" (YL J4). Alkitab merupakan petunjuk dan pedoman hidup bagi umat Kristen (RD J4), pemahaman Alkitab adalah bahwa pemahaman Alkitab sangat bermanfaat bagi para pemuda dalam hal pengetahuan akan Alkitab yang lebih mendalam dan mendasar akan kebenaran Firman Tuhan (FI J4), pemahaman Alkitab itu ialah kewajiban umat Kristen dan di dalam Alkitab itu kita belajar tentang isi Alkitab dan bisa merenungkan apa saja yang ada di dalam Alkitab. Di situ pula di dalam Alkitab itu kita bisa belajar isi Alkitab tentang saling mengasihi, saling mengampuni (TU J4), narasumber yang terakhir berpendapat tentang 
pemahaman Alkitab adalah buku yang menyelamatkan (GU J4).

Alkitab merupakan pengilhaman Ilahi yang berisikan catatan otoritatif mengenai hubungan antara Allah dengan manusia. Kelima narasumber mempunyai Pemahaman isi Alkitab yang berbeda yaitu isi Alkitab mengajarkan kita untuk menghormati ayah dan ibu supaya lanjut usia mu di tanah yang di janjikan oleh Tuhan dan mendapatkan umur panjang (YL J5). Dengan melakukan pemahaman Alkitab kita akan mengetahui apa yang Tuhan mau kita lakukan dikehidupan seharihari (RD J5), dengan melakukan pemahaman Alkitab maka makna dan maksud dari tujuan Firman Tuhan yang tersirat dalam Isi Alkitab dapat dipahami dan dimengerti sesuai dengan maksud dari isi Alkitab tersebut (FI J5). Alkitab itu adalah renungan Firman Tuhan yang setiap kali kita dengar, dan bisa melakukan dalam kehidupan sehari-hari (TU J5). Alkitab sebagai Firman yang menyelamatkan hidup saya (GU J5).

Pemahaman Alkitab perlu dilakukan sebab dengan memahami isi Alkitab maka kita akan berjalan dijalan yang benar sesuai dengan Firman Tuhan yang terkandung di dalam Alkitab. Terkait dengan hal ini, kelima narasumber mengatakan bahwa pemahaman Alkitab perlu di lakukan karena Alkitab mengajarkan hal-hal yang sangat baik dalam kehidupan manusia (YL J6). Pemahaman Alkitab perlu dilakukan karena tanpa melakukan pemahaman Alkitab kita tidak akan tahu isi hati Tuhan dan iman kita tidak akan bertumbuh (RD J6). Pemahaman Alkitab sangat perlu dilakukan karena dengan melakukan pemahaman Alkitab maka kita akan semakin memahami isi Alkitab (FI J6), karena dalam Alkitab kita bisa membaca, merenungkan dan melakukan dalam kehidupan kita seharihari (TU J6), karena di dalam Alkitab kita bisa mengetahui kehidupan Yesus Kristus yang telah berkorban menyelamatkan hidup kita sampai saat ini (GU J6).

\section{Retret}

Masyarakat awam menilai bahwa retret merupakan Ibadah sambil berekreasi, namum arti sesungguhnya dari retret adalah sebuah metode yang dilakukan oleh gereja untuk membentuk, membina dan memelihara iman Kristiani anggota jemaat. Berikut pemahaman dari kelima narasumber 
tentang retret berdasarkan hasil wawancara. Pemahaman saya tentang retret adalah ibadah yang mendorng kerohanian kita kepada Tuhan sangat dekat yang di mana ibadah tersebut selalu mengajak kita kepda Tuhan (YL J7). Retret merupakan kegiatan yang dilakukan bersama suatu kelompok diluar ruangan yang dapat dilakukan ditempat wisata (RD J7). Pemahaman saya tentang retret adalah bahwa dengan adanya retret maka kita tidak kaku dalam pengajaran Alkitab tetapi kita merasa fleksibel dan dapat merefleksikan diri kita dalam iman akan Yesus Kristus (FI J7). Pemahaman saya tentang retret itu kita harus melakukan ibadah di suatu tempat untuk merefleksikan diri kita di situ pula kita bisa tahu apa isi Alkitab dan apa yang kita tidak tahu di dalam Alkitab itu pasti kita tahu (TU J7). Pemahaman saya tentang retret yaitu retret ini di lakukan di mana saja. Jadi, kita bisa melatih iman kita lebih dewasa, kita juga bisa memahami situasi atau lingkungan yang kita mau melakukan ibadah ini (GU J7).

Menurut sebagian besar jemaat bahkan seluruh jemaat dalam sebuah gereja, mereka menilai bahwa retret perlu dilakukan dengan tujuan mencari suasana baru dalam melakukan ibadah. Kelima narasumber mempunyai pendapat masing - masing terkait perlu dilakunnya kegiatan retret yaitu retret perlu di lakukan karena ibadah tersebut menambah kerohanian manusia dalam berlingkungan yang baik (YL J8). Retret perlu dilakukan karena dapat memberikan suasana baru dalam melakukan ibadah pemuda yaitu hubungan sesama pemuda menjadi akur dan menikmati pemahaman Alkitab sambil berrekreasi (RD J8). Retret perlu dilakukan agar pemuda/pemudi dapat merefleksikan dirinya dalam iman akan Yesus Kristus (FI J8), retret perlu dilakukan karena mungkin dalam kehidupan kita, kita tidak pernah melakukan ibadah, tidak mendengarkan Firman Tuhan dan kita harus mengikuti retret supaya kita belajar tentang isi Alkitab tersebut (TU J8), retret perlu dilakukan karena salah satu cara atau ibadah sehingga bisa menambah iman kita (GU J8).

Tidak ada semua kegiatan yang berjalan dengan mulus. Dalam melaksanakan sebuah kegiatan, pasti ada saja kendala atau hambatan yang ditemui. Berikut pendapat narasumber tentang hambatan dalam melaksanakan 
kegiatan reteret. Menurut saya tidak ada hambatan dalam retret (YL J9), menurut saya ada hambatan sepertinya kesiapan setiap anggota, cuaca dan lamanya perjalanan (RD J9), menurut saya ada hambatan dalam pelaksanaan retret yaitu hambatan dalam pelaksanaan kegiatan pelayanan Firman yang tidak tepat dengan keadaan para pemuda maka akan semakin tidak terarah pelayanan kepada pemuda pemudi (FI J9). Menurut saya tidak ada hambatan hanya semua itu semata-mata dalam diri kita. Semua ibadah yang dilakukan tetapi kita yang tidak melakukan, karena semua dari kesibukan kita. Setiap kali beribadah kita sibuk dengan pekerjaan kita. Sehingga membuat kita tidak bisa melakukan ibadah itu (TU J9), menurut saya hambatan itu hanya kembali pada diri kita (GU J9).

\section{Musyawarah Belajar (Musbel)}

Musyawarah belajar dalam konteks gerejawi yaitu sebagai wadah untuk belajar memperkuat spiritualitas iman dan pekah terhadap aneka persoalan yang terjadi ditengah masyarakat. Berikut Pemahaman kelima narasumber tentang Musbel. Musbel merubah pola pikir pemuda berkerohanian dalam berlingkungan yang baik (YL J10). Pemahaman saya tentang musbel yaitu untuk meningkatkan pengetahuan dan merubah pola pikir pemuda/pemudi (RD J10), menurut saya musbel sangat bermanfaat bagi pelayanan dalam gereja untuk pertumbuhan iman jemaat (FI J 10). Menurut saya musbel adalah suatu ibadah yang sangat penting tetapi di dalam diri kita, kita menganggap ibadah itu tidak penting, tetapi di dalam Alkitab mengatakan bahwa beribadah itu sangat penting (TU J10), pemahaman saya tentang musbel yaitu kegiatan yang menambah wawasan kita di masyarakat dan jemaat ( GU J10 ).

Musbel sangat perlu dilakukan. Hal ini juga disampaikan oleh kelima narasumber berdasarkan hasil wawancara, dimana kelima narasumber menginginkan agar Musbel perlu dilakasanakan. Berikut kutipan pendapat narasmeber tentang pentingnya diadakan musbel. Menurut pendapat saya, perluh di lakukan karena musbel mendorong pola pikir kerohanian yang baik (YL J11). Menurut saya perlu dilakukan, karena dengan kegiatan musbel pemuda menjadi lebih berani dan percaya diri (RD J11). Menurut saya musbel sangat 
perlu dilakukan karena dapat menumbuhkan iman jemaat dengan baik (FI J11), menurut saya musbel sangat perlu dilakukan karena setiap kali ada kegiatan atau ibadah-ibadah kita tidak pernah melakukan ibadah, dan tidak mengikuti ibadah tersebut (TU J11), menurut saya musbel sangat perlu dilakukan karena musbel ini kita belajar hal-hal penting yang di sampaikan, dan kita juga bisa menyampaikan pendapat kita (GU J11).

Seperti yang dijelaskan pada pembahasan sebelumnya, bahwa setiap kegiatan yang dilaksanakan, pasti ada hambatannya. Narasumber juga menyadari akan hal itu. Berdasarkan hasil wawancara, tiga narasumber mengatakan bahwa ada hambatan pada musbel sedangkan dua narasumber mengatakan tidak ada hambatan dalam Musbel. Menurut saya tidak ada hambatan (YL J12), hambatan dalam musbel yakni ada pemuda/pemudi yang tidak serius dalam melakukan kegiatan musbel (RD J12), tidak ada hambatan dalam pelaksanaan musbel (FI J12). Hambatan terbesar dalam kegiatan Musbel datang dari diri kita sendiri karena diri kitalah yang menjadi suatu hambatan untuk ibadah tersebut (TU J12 GU J12).

\section{Pembahasan}

\section{Ibadah Pemuda}

Berdasarkan wawancara yang dilakukan, Ibadah pemuda dilakukan setiapa hari Senin dengan melibatkan semua pemuda yang berada di jemaat Yedidyah Abangiwang. Pemuda berada pada umur 18-34 tahun, pada umur ini sudah mampu berpikir dan penuh citacita masa depan seperti kuliah, mencari pekerjaan dan penentuan pasanga hidup (Kristianto 2006:129-130). Melihat usia pemuda berdasarkan pendapat tersebut maka alangkah Ibadah pemudah dilakukan pada hari Senin sangatlah tepat karena pada kisaran usia tersebut merupakan usia - usia yang produktif dalam bekerja sehingga sangat efektif apabila ibadah dilakukan pada hari Senin karena ibadah dilakukan pada awal minggu sehingga memberi semangat dan motivasi dalam manjalani hari-hari berikutnya.

Menurut Herber C. Quay (1965: 41) kriminal dilakukan dengan sistem urat syaraf diporeaktif dan otak yang kurang memberi respon, keadaan demikian tidak terjadi dalam vakum, 
melainkan berinteraksi dengan tujuan tempat tinggal tertentu dimana individu hidup dalam pergaulan. Berdasarkan pendapat tersebut maka faktor utama dari seseorang melakukan sebuah tidakan kriminal adalah lingkungan tempat dia berada dan dengan siapa dia bergaul serta berinteraksi. Terkait dengan penjelasan ini maka bisa dikatakan bahwa pemuda Jemaat Yedidtyah Abangiwang tidak terpengaruh dengan hal - hal kriminal, sebab lingkungan dimana mereka tinggal selalu melakukan Ibadah Pemuda setiap hari Senin. Dimana Ibadah Kristen adalah jawaban manusia terhadap panggilan ilahi terhadap tindakan-tindakan yang penuh kuasa Allah, yang berpuncak dalam tindakan pendamaian dalam Kristus (White, 2009: 6-8). Berdasarkan pendapat White tersebut maka Ibadah pemuda mempunyai pengaruh yang sangat besar untuk meminimalisir tindakan kriminal sebab tindakan - tindakan yang dilakukan oleh pemuda setelah mengikuti Ibadah pemuda adalah tindakan-tindakan yang penuh kuasa Allah. Artinya bahwa ketika para pemuda mengikuti Ibadah dan mendengarkan firman Tuhan maka roh
Allah bekerja di dalam hati mereka, sehingga tidak ada pemikiran mereka untuk melakukan hal - hal yang berbau kriminal.

\section{Pemahaman Alkitab}

Berdasarkan hasil wawancara
yang dilakukan, Narasumber
mengatakan bahwa pemahaman Alkitab mendorong dan mengajarkan pada hal hal baik yang di mana salah satu kitab mengajarkan kepribadian saya tentang berlingkung yang baik, jangan mengini barang sesama, hormatilah ayah dan ibumu supaya lanjut usia mu. Hal ini berarti bahwa Narasumber dapat memahami isi Alkitab terutama didalam kitab Keluaran 20:2-17 dan Ulangan 5:6-21, yang memuat tentang Hukum Taurat. Berdasarkan pemaparan dari Narasumber, dapat disimpulkan bahwa pemehaman Alkitab dapat mendorong dan mengajarkan tentang hal - hal yang baik karena pada dasarnya Hukum Taurat mengajarkan Tentang hal - hal yang dilarang dan dikehendaki Oleh Tuhan.

$$
\begin{aligned}
& \text { Berdasarkan hasil wawancara } \\
& \text { yang dilakukan, Narasumber } \\
& \text { mengatakan bahwa Alkitab merupakan } \\
& \text { petunjuk dan pedoman hidup bagi umat } \\
& \text { Kristen. Ini berarti bahwa narasumber }
\end{aligned}
$$


memahami Alkitab sebagai Petunjuk dan pedoman hidup bagi pemuda pemudah Kristen sebab Alkitab merupakan Karya Roh kudus yang membenarkan kejadian - kejadian selektif dan ketepatan penyampaian penafsiran untuk mencapai kehendak Allah pada umat manusia (Dewey Beegle, 1963: 190). Itu berarti bahwa dengan memahami Isi Alkitab yang menurut narasumber sebagai Petunjuk dan Pedoman hidup maka pemuda akan melakukan hal - hal yang dikehendaki Allah yaitu Melakukan perintah-Nya dan menjauhi larangan-Nya.

Berdasarkan hasil wawancara, Narasumber mengatakan pendapatnya tentang pemahaman Alkitab adalah bahwa pemahaman Alkitab sangat bermanfaat bagi para pemuda dalam hal pengetahuan akan Alkitab yang lebih mendalam dan mendasar akan kebenaran Firman Tuhan. Alkitab merupakan kitab suci orang Kristen yang dipercaya sebagai Firman Allah (Willy Sualang, 2015:5). Berdasarkan definisi tersebut maka sebagai orang Kristen, patutlah memahami isi Alkitab karena Alkitab merupakan kitab suci orang Kristen. Dengan memahami isi Alkitab maka hidup akan mengarah kepada hal - hal yang dikehendaki Tuhan, dimana hal - hal yang dikehendaki Tuhan adalah Mengikuti Perintah serta menjauhi larangan-Nya, yang termuat didalam Hukum Taurat.

Berdasarkan hasil wawancara, Narasumber mengatakan bahwa yang dia pahami tentang isi Alkitab adalah menghormati ayah dan ibu supaya lanjut usia mu di tanah yang di janjikan oleh Tuhan dan mendapatkan umur panjang. Pendapat narasumber ini lebih kepada hukum taurat dimana dia menjadikan hukum kelima sebagai dasar baginya dalam memahami isi Alkitab. Namun inti dari pada hukum taurat yang sebenarnya adalah kasihilah Tuhan Allah mu dengan segenap akal budimu dan kasihilah sesamamu manusia seperti dirimu sendiri. Ini berarti bahwa salah satu bentuk pemahaman isi Alkitab yang Tuhan kehendaki untuk manusia adalah Kasih.

Berdasarkan hasil wawancara yang dilakukan, Narasumber berpendapat bahwa dengan melakukan pemahaman Alkitab kita akan mengetahui apa yang Tuhan mau kita lakukan dikehidupan sehari- hari. Hal ini sangat jelas sebab Alkitab merupakan Karya Roh kudus yang 
membenarkan kejadian - kejadian selektif dan ketepatan penyampaian penafsiran untuk mencapai kehendak Allah pada umat manusia (Dewey Beegle, 1963 : 190). Itu berarti bahwa semakin sesorang belajar untuk memahami isi Alkitab, maka semakin jelas ia akan mengerti tentang apa yang dikehendaki oleh Tuhan dalam kehidupannya sehari - hari.

\section{Musyawarah Belajar (Musbel)}

Berdasarkan wawancara yang dilakukan, kelima Narasumber memiliki persamaan pemahaman terkait dengan musbel yaitu meningkatkan wawasan pengetahuan jemaat, merubah pola pikir berkerohanian pemuda dalam berlingkungan yang baik serta menumbuhkan iman pemuda jemaat. Musbel merupakan wadah untuk belajar saling berbagi pengalaman dan pengetahuan kapasitas dan spiritual diri. Kapasitas adalah kemampuan untuk melakukan tugas - tugas yang sesuai secarah efektif, efisien, dan berkelanjutan (Grindle, 1997: 34). Sedangkan dari aspek pertumbuhan iman, dapat dikaji dari segi ibadah dimana Musbel juga merupakan salah satu bentuk dari ibadah sebab ibadah yang memberikan pertumbuhan dan kedewasaan Iman adalah Ibadah yang membawa pemuda hari demi hari semakin mengenal Allah sebab didalam Ibadah terdapat pembacaaan dan renungan Alkitab yang dapat menumbuhkan pertumbuhan Iman karena didalam Alkitab, terdapat tujuh cara yang dapat menguatkan pertumbuhan iman pemuda yaitu menaikan pujian dan menyampaikan ucapan syukur kepada Allah, mengakui dosa kepada Allah, berdoa kepada Allah, berpegang ada Firman Allah, percaya akan kemenangan hidup setiap hari, bersaksi tentang apa yang dilakukan Allah dan yang terakhir adalah bekerja terus dan melayani Tuhan dan sesama dengan bersandar kepada pimpinan Roh kudus (Ichwei G. Indra, 2001 :51). Berdasarkan hasil wawancara yang dilakukan, narasumber mengatakan bahwa Musbel perlu dilakukan karena musbel mendorong pola pikir kerohanian yang baik.

\section{PENUTUP}

\section{Kesimpulan}

Berdasarkan hasil penelitian, dapat disimpulkan bahwa: Ibadah Pemudah, Pemahaman Alkitab, Retret dan Musyawarah Belajar (Musbel) yang 
dilakukan di Jemaat Yedidiah Abangiwang sangat membantu Pemuda untuk tidak terpengaruhi dengan hal-hal Kriminal, memberi semangat dan motivasi dalam manjalani kehidupan sehari - hari, menumbuhkan iman dan pengenalan akan Yesus Kristus Sang Juruselamat, merubah kepribadian pemuda kearah yang lebih baik. dapat membekali pemuda dengan pengetahuan dan pemahaman Alkitab, serta meningkatkan peran pemuda dalam kegiatan - kegiatan keagamaan.

\section{REFERENSI}

Turang. Petrus. (2006). Kaum Muda, Misa Dan Misi. Kupang: 13 Maret 2006.

Alen. Judith. Shelly, (2003). Kebutuhan Rohani Anak Pedoman Untuk Para Orang Tua, Guru dan Perawat. Bandung: Kalam Hidup.

Thayer. H. Joseph. (2007). Thayer's Greek-English Lexicon of the New Testament. Massachusetts: Hendrikckson Publisher.

Prof. Dr. Sugiyono (2018). Metode Penelitian Kuantitaif, Kualitatif, dan RdD. Alfabeta, Bandung.

Kristianto Lilik Paulus. (2006). Prinsip dan praktik pendidikan Agama Kristen, Yogyakarta: Andi
Herber C. Quay (1965). Pathological Simulation Seeking, CV Bina Nanggroe

White F. James (2001). Pengantar Ibadah Kristen. BPK Gunung Mulia.

Dewey Beegle (1963). Inspiration of Cripture, Trinity evangelical Divinity School.

Sualang Willy (2015). Dasar Alkitabiah Penelaan, Jakarta:BPK

Grinnell. Ann. (2011). Dream Big, Start Small. Jakarta: Departemen Pemuda GKII dan CMA.

Ichwel G. Indra (2001). Perjumpaan Iman Kristen dan Kebudayaan, Baptis : Bandung 